УДК 373.3:37.015.31:57.081.1

DOI https://doi.org/10.26661/2522-4360-2021-2-31

\title{
ФОРМУВАННЯ ЕКОЛОГІЧНОЇ КУЛЬТУРИ СТУДЕНТІВ ЕКОНОМІКО-ГУМАНІТАРНИХ ТА ІНЖЕНЕРНИХ КОЛЕДЖІВ ЗАСОБАМИ ІНТЕГРАТИВНОГО ПІДХОДУ
}

\author{
Трофімчук Н. В. \\ аспірантка кафедри суспільних дисииплін \\ Національний університет водного господарства та природокористування \\ вул. Соборна, 11, Рівне, Україна \\ orcid.org/0000-0002-9597-1293 \\ nataliatrofimcuk66@gmail.com
}

\author{
Ключові слова: екологічна \\ культура, екологічна освіта, \\ інтеграція, педагогічна \\ інтеграція, \\ інтегративний підхід.
}

У статті експліковано поняття екологічної культури та іiі формування засобами інтегративного підходу. Зокрема, визначено, що екологічна культура являє собою систему взаємозалежностей та взаємоадаптації людини i природи на основі культурних традицій, емоційноціннісних переживань. Така адаптація забезпечує збалансованість та урівноваженість людського буття i дозволяє людині долати власну природну обмеженість. Екологічна культура входить у зміст душевних прагнень і спонук, переломлюючись крізь людську суб'єктивність у іiі нерозривному зв’язку зі світом.

Доведено, що екологічна культура вибудовується на інтегративній основі, щоразу залучаючи у власний обіговий контекст нові види пізнання. Інтегративний підхід кваліфікуємо як стратегію дослідження процесу формування екологічної культури студентів економіко-гуманітарних та інженерних коледжів, що усуває фрагментацію знань про реальність, вибудовуючи цілісну картину світу. Ідея інтеграції пронизує сучасний освітньо-педагогічний простір і є однією 3 домінантних, оскільки вона ретранслює динаміку парадигмальних педагогічних зрушень в умовах переходу від традиційних моделей структурування знань лінійного типу до більш складних, від статичних до динамічних. Визначення змісту освітніх процесів неодмінно супроводжується урахуванням їх множинності та варіативності, що націлює на побудову синтетичної освітньої моделі та розвиток інтегративних процесів в освіті.

Використання інтегративного підходу у формуванні екологічної культури студентів кваліфікуємо як необхідний елемент цілісного освітньо-виховного процесу економіко-гуманітарних та інженерних коледжів, де інтеграція традиційно представлена блоком нормативних дисциплін, кожна з яких так чи інакше актуалізує попередньо набуті знання. Така послідовність в оволодінні необхідним каркасом знань репрезентує інтегративну вертикаль предметно орієнтованого навчання. У коледжах інтегративна модель оволодіння знаннями не обмежується вимогами щодо їх нарощування та сумування, а передбачає взаємодію та взаємодоповнення дисциплін. 


\title{
FORMATION OF ECOLOGICAL CULTURE OF STUDENTS ECONOMICS, HUMANITIES AND ENGINEERING COLLEGES BY MEANS OF AN INTEGRATIVE APPROACH
}

\author{
Trofimcuk N. V. \\ Postgraduate student at the Department of Public Disciplines \\ National University of Water Management and Natural Management \\ Soborna str., 11, Rivne, Ukraine \\ orcid.org/0000-0002-9597-1293 \\ nataliatrofimcuk66@gmail.com
}

Key words: ecological culture, environmental education, integration, pedagogical integration, integrative approach.

\begin{abstract}
The article explicted the concept of ecological culture and its formation by means of an integrative approach. In particular, it is determined that ecological culture is a system of interdependencies and the adaptation of man and nature on the basis of cultural traditions, emotional and value experiences, which provides balance and balancing of human being and allows a person to overcome their own natural limitations. Environmental culture is included in the content of mental aspirations and motion, turning through the human subjectivity in its inextricable connection with the world.

It is proved that ecological culture is built on an integrative basis, while attracting new types of knowledge into its own circular context. An integrative approach qualify as a strategy for studying the process of forming the ecological culture of students of economic and humanitarian and engineering colleges, which eliminates the fragmentation of knowledge about reality, building a coherent picture of the world. The idea of integration through the contemporary educational and pedagogical space and is one of the dominant, as it relays the dynamics of paradigmatic pedagogical changes in the transition from traditional models of structuring of linear type knowledge to more complex, from static to dynamic. Determination of the content of educational processes is necessarily accompanied by taking into account its multiplicity and polyvariative, which targeting the synthetic educational model and the development of integrative processes in education.

The use of an integrative approach in the formation of environmental culture of students qualify as a necessary element of a holistic educational process of economic and humanitarian and engineering colleges, where integration is traditionally represented by a block of normative disciplines, each of which one way or another actually acquires the previously acquired knowledge. Such a sequence in mastering the necessary knowledge frame represents an integrative vertical subject-oriented learning. In colleges, the integrative model of mastering knowledge is not limited to the requirements of their buildup.
\end{abstract}

Постановка проблеми. Феномен екологічної культури, що пов'язана 3 проблемами людського виживання в умовах природних загроз і катаклізмів та подолання різних екологічних небезпек, нині постає стратегічною метою сучасної освіти. Екологічна культура являє собою систему взаємозалежностей та взаємоадаптації людини і природи на основі культурних традицій, емоційно-ціннісних переживань. Така адаптація забезпечує збалансованість та урівноваженість людського буття і дозволяє людині долати власну природну обмеженість. Людина немов приміряє і пристосовує до себе світ, у якому вона живе, вловлюючи його живий нерв і пульсацію життєвої енергії. Охоплюючи широкий спектр людської реальності, екологічна культура постає як інтегративне утворення, що визначає зміст сучасних освітніх процесів. Ідея інтеграції нині $€$ однією $з$ домінантних, оскільки вона ретранслює динаміку парадигмальних педагогічних зрушень в умовах переходу від традиційних моделей структурування знань лінійного типу до більш складних, від статичних до динамічних. Дозволяючи уникнути однобокість та одноплощинність наукової стратегії і постаючи основною умовою модернізації змісту освіти, вона націлює 
на побудову синтетичної освітньої моделі та розвиток інтегративних процесів в освіті.

Ідея метапарадигмального синтезу, що передбачає цілісність досліджуваного освітнього поля зі збереженням методологічного плюралізму та множинністю його репрезентацій, уперше була експлікована у дисертаційному дослідженні М. Романенка «Соціальні та парадигмальнокогнітивні детермінанти розвитку сучасної освіти». Саму ж процедуру метапарадигмального синтезу запропоновано автором для системного аналізу та класифікації парадигмально-когнітивних основ постсучасних освітніх теорій та практик [17].

Про широкі можливості інтеграції в педагогічному процесі, «ііі об’єктивну необхідність, форми прояву, механізми реалізації та вплив на структуру педагогічного знання та освіти» говорить В. Безрукова [2, с. 3]. Характеризуючи категоріальний статус інтеграції в педагогіці, дослідниця вказує на триєдність іiї семантичного поля. Зокрема, вона розглядає це поняття як процес $\mathrm{i}$ результат цього процесу, а також тенденцію, яку можна кваліфікувати водночас як принцип розвитку теорії і практики. Саме в такому зрізі пропонує аналізувати поняття інтеграції В. Шярнас $[24$, C. $7-10]$. Зважаючи на поліфункціональність та багатоплановість зазначеного поняття, а також переобтяженість його великою кількістю різноманітних характеристик, дослідник наголошує на неможливості його єдиного визначення. Нині феномен інтеграції центрує освітній пошук таких науковців, як О. Савченко, Н. Бібік, В. Ільченко, Т. Пушкарьова, Л. Масол, О. Гайдамака, Н. Очеретяна, О. Сухаревська та ін., у дослідженнях яких інтеграція позначає підпорядкування єдиній виховній і навчальній меті однотипних частин та елементів змісту, методів і форм у рамках освітньої системи на певній стадії навчання $[19$, с. 9]. Теоретико-методологічну основу інтеграції розроблено I. Козловською, яка вбачає у ній процес взаємодії елементів, наділених відповідними властивостями, що передбачає встановлення, ускладнення та інтенсивність істотних зв'язків між ними [10]. Це значною мірою впливає на те, що наслідком вказаної взаємодії стає новий інтегрований об'єкт, який володіє якісно відмінними трансформованими властивостями і містить кардинально нові системні властивості цілого, проте зберігає у своїй структурі індивідуальні ознаки вихідних елементів. Таким чином, інтегрування постає як якісно новий, динамічний і суперечливий процес структурування знань у нових органічних взаємозв'язках. Досліджуючи сутнісні ознаки цього процесу, I. Козловська переконує у необхідності створення передумов об'єднання попередньо розрізнених елементів, але не шляхом простого сумування, а шляхом синтезу, результа- том якого має бути система, ключовою ознакою якої дослідниця вважає цілісність. Саме ця інтегративна система екологічних та культурних взаємозв'язків і взаємовпливів потребує нині ширшої наукової палітри.

Метою статті $\epsilon$ дослідження процесу формування екологічної культури студентів економіко-гуманітарних та інженерних коледжів засобами інтегративного підходу.

Виклад основного матеріалу дослідження. Прикметно, що ідея інтеграції найкраще узгоджується 3 методологічними засадами холістичної парадигми, яка засвідчує планетарні зусилля глобалізованого світу, спрямовані на збереження власної цілісності і неподільності. Якщо ж брати до уваги холістичну педагогіку, то найпродуктивнішою іїі ідеєю треба визнати ідею цілісності суб'єкта, неподільності і незбагненності людської душі. У вимірах холізму, вибудуваного на інтегративних засадах, екологічна культура входить у зміст душевних прагнень і спонук, переломлюючись крізь людську суб'єктивність у ії нерозривному зв'язку зі світом.

Педагогічна інтеграція як принцип розвитку педагогічної теорії і практики найпосутніше відображає специфіку сучасного стану педагогічної науки і володіє необхідним арсеналом впливу на усі іiі сфери і явища. Поняття «інтеграція» (від лат. "integration" - «відновлення, поновлення» та "integer" - «цілий») тлумачиться як доцільне об'єднання та координація дій різних частин цілісної системи [5, с. 401], процес розвитку, пов'язаний з об'єднанням в єдине ціле розрізнених частин і елементів, результатом якого є певний ступінь інтегрованості - стан упорядкованого функціонування частин цілого [22, с. 595]. Як зауважує I. Бех, наявна «стадія наукового мислення дедалі більше характеризується прагненням розглядати не окремі, ізольовані об'єкти явища життя, a їх більш чи менш широкі єдності. Отже, інтеграція як вимога об'єднання в ціле якихось частин чи елементів вважається необхідним дидактичним засобом, за допомогою якого можна створити в учнів цілісну картину світу» [3, с. 5]. Водночас Н. Бордовська відстежує тенденцію до зростання теоретичної множинності педагогіки [4, с. 292], а це, на думку дослідниці, засвідчує потребу нових методологічних підходів для осмислення та визначення шляхів іiі розвитку. В Оксфордському тлумачному словнику інтеграція розглядається як акт чи процес поєднання двох або більше частин таким чином, щоб вони функціонували злагоджено [26, с. 675].

Процеси, які відстежуємо у рамках наявної системи, сприяють підвищенню рівня ії цілісності та організованості, інтенсифікуючи відповідні зв'язки між структурними елементами 
системи, що засвідчено Державною національною програмою «Освіта» («Україна XXI століття»), Національною доктриною розвитку освіти України, Концепцією нової української школи, у якій, зокрема, запропоновано «навчальний матеріал < ..> інтегрувати в змісті споріднених предметів або вводити до складу предметів у вигляді модулів» [11]. Процес інтеграції є одним із найбільш сучасних інноваційних підходів в освітньому полі України. Доцільно підкреслити, що поняття інтеграції уперше було озвучене у 30-х рр. XX ст. Його семантичне поле формувалося упродовж тривалого часу, що засвідчують праці Й. Песталоцці, Й. Гербарта, К. Ушинського, Г. Сковороди тощо. Так, основоположник наукової педагогіки й народної школи К. Ушинський стверджує, що знання та ідеї, які розробляються різними науками, повинні органічно вбудовуватися у світлий і панорамний погляд на світ [21], а в основу виховання людини має покладатися цілісне людинознавство. Отже, без всебічного вивчення людини педагогіка $є$ немислимою. Зауважимо, що започаткованій ним педагогічній антропології, яка синтезує та систематизує знання про людину, він надавав статусу методологічного фундаменту педагогіки. Основною педагогічною думкою Г. Сковороди було природне виховання, що передбачало виховання цілісного духу, гармонійної особистості, що живе у злагоді із собою. Предметом педагогічної думки мислителя була людина, iii думки, душа, дух, серце, розум, що разом засвідчували ідею людини як складної системи, яка вимагає делікатного ставлення до себе. Так, Г. Сковорода зазначав: «Часто ми найдрібніших дрібниць не розуміємо. А людина-це маленький світ, мікросвіт, силу якого важко осягнути так, як неможливо відшукати початок Всесвіту» [18, с. 174].

Наріжною проблемою сучасного педагогічного знання стає дезактуалізація його винятково прикладних аспектів, що виходять за межі власної змістової конкретики, потребуючи узагальнень та фундаменталізації. Ми погоджуємося з О. Сухомлинською, яка фіксує відчутний відрив усієї педагогічної науки від практики. Кардинальні зміни та інноваційні процеси, що відстежуються в системі освіти, засвідчують прагнення науковців «3 одного боку, знайти й аргументувати нові засади, нову парадигму своєї науки, а 3 другого - науково описати, підвести науковий фундамент під сучасні інноваційні процеси, що відбуваються в освітньому просторі України» [20, с. 3-4].

Такі міркування покладаються в основу обгрунтування інтегративного підходу, що включає інтеграцію в ролі принципу конструювання системи і забезпечує доцільне об'єднання і синтез компонентів змісту навчання внутрішньопредметного та міжпредметного характеру, їх узагальнення на рівні фактів, понять, теорій, ідей, формування цілісної системи узагальнених знань, способів і видів діяльності [16].

Ідея інтегративного підходу в освітньому процесі пронизує праці О. Дубасенюк [8, с. 17-20], Н. Антонова [11], Є. Галицьких [11], І. Яковлєва [25] та ін. Так, О. Дубасенюк трактує цей підхід як стратегію дослідження процесу, базову ціннісну орієнтацію, яка визначає позицію педагога [8, с. 17-20], а В. Лопаткін вважає його засобом, що забезпечує «цілісність картини світу, сприяє розвитку здібностей системного мислення у процесі розв'язання теоретичних і практичних завдань» [14]. Зауважимо, що Л. Гриценко пов'язує інтегративний підхід із розробкою методів діяльності, конструюванням складних об'єктів, що перебувають у процесі розвитку, та їх дослідженням на підставі об'єднання в єдине ціле їх розмаїтих властивостей, моделей та концепцій [7]. Н. Мойсеюк трактує інтегративність як орієнтацію на інтегральні курси, пошук нових підходів до структурування знань як засобу цілісного розуміння та пізнавання світу [15, с. 139].

На нашу думку, інтегративний підхід являє собою стратегію дослідження процесу формування екологічної культури студентів економіко-гуманітарних та інженерних коледжів, що усуває фрагментацію знань про реальність, вибудовуючи цілісну картину світу. У контексті сказаного стає очевидним те, що екологічні уміння та навички мають стати не просто об'єктом засвоєння знань, а отримати статус психолого-педагогічного фактора особистісного розвитку, вироблення особистісних цінностей, які передбачають не тільки активну соціальну взаємодію, а й відповідні відносини з природою як екосистемою, у якій людині відведена не остання роль. Отже, ідея інтегрування набула нині наскрізного характеру i охоплює усі сфери педагогічного знання.

Прикметно, що Концепція екологічної освіти України серед стратегічних напрямів і тактичних завдань розвитку вказує на потребу формування поколінь $з$ новою екологічною культурою, новим екологічним світоглядом на принципах гуманізму, екологізації мислення, міждисциплінарної інтеграціï, історизму та системності з метою збереження і відновлення природи України та їі біологічного різноманіття, а також на потребу екологізації навчальних дисциплін та програм підготовки [11].

Зауважимо, що програма фахової підготовки студентів економіко-гуманітарних та інженерних коледжів передбачає вивчення ними дисциплін загальноосвітньої підготовки та отримання освітньо-кваліфікаційного рівня «молодший спеціаліст», що згідно із Законом України «Про вищу освіту» являє собою освітньо-кваліфікаційний рівень вищої освіти особи, яка на основі повної 
загальної середньої освіти здобула неповну вищу освіту, спеціальні уміння та знання, достатні для здійснення виробничих функцій певного рівня професійної діяльності, що передбачені для первинних посад у певному виді економічної діяльності [9, с. 74-121]. Як зауважує М. Хилько, нині суттєво розширилося коло наук, що експлікують екологічну проблематику. До них, зокрема, віднесено біологію, економіку, географію, а також медичні й соціологічні дослідження. На думку дослідника, екологія, прагнучи асимілювати наявні проблеми природознавчого та соціогуманітарного профілю, не тільки значно розширює власне предметне поле, а й так чи інакше претендує на певне лідерство в науковому пізнанні, а тому їі не варто «втискувати в рамки виключно природознавства чи соціології» [23]. Не буде помилкою визнати, що сучасна екологічна культура вибудовується на міждисциплінарній основі, щоразу залучаючи у власний обіговий контекст нові види пізнання, а тому вона постає відкритою системою, що передбачає координацію змісту навчальних дисциплін, їх взаємодію на єдиній мотиваційній основі. Таким чином, використання інтегративного підходу у формуванні екологічної культури студентів ми кваліфікуємо як необхідний елемент цілісного освітньо-виховного процесу економіко-гуманітарних та інженерних коледжів, де інтеграція традиційно представлена блоком нормативних дисциплін, кожна 3 яких так чи інакше актуалізує попередньо набуті знання. Така послідовність в оволодінні необхідним каркасом знань репрезентує інтегративну вертикаль предметно орієнтованого навчання. У коледжах інтегративна модель оволодіння знаннями не обмежується вимогами щодо їх нарощування та сумування, а передбачає взаємодію та взаємодоповнення дисциплін.

3 огляду на це ми маємо визначити такі дисципліни, які найбільшою мірою сприяють формуванню екологічної культури студентів економіко-гуманітарних та інженерних коледжів. 3 одного боку, до них доцільно віднести еколого-біологічні та валеологічні дисципліни, що взаємно детермінуються, формуючи еколого-валеологічний категоріальний апарат мислення. Вони значною мірою впливають на рівень сформованості еколого-валеологічних цінностей. Ідеться про біологію та екологію, безпеку життєдіяльності, гігієну, анатомію і фізіологію людини тощо. 3 іншого боку, підготовка випускників економіко-гуманітарних та інженерних коледжів має бути представлена такими дисциплінами: «Фізичне виховання», «Культурологія», «Основи філософських знань» тощо. Так, аналіз навчальної програми дисципліни «Біологія і екологія», затвердженої Міністерством освіти і науки України (наказ № 1407 від
23.10.2017 р.), дозволив з'ясувати, що їі метою $\epsilon$ формування в учнів природничо-наукової компетентності шляхом засвоєння системи інтегрованих знань про закономірності функціонування живих систем, їх розвиток і взаємодію, взаємозв'язок із довкіллям; розуміння біологічної картини світу та цінності таких категорій, як життя, природа, здоров'я; свідомого ставлення до природи як універсальної, унікальної цінності; застосування знань з біології та екології у повсякденному житті, оцінювання їх ролі для сталого (збалансованого) розвитку людства, науки та технологій.

Програма інтегрованого курсу охоплює такі теми: «Біорізноманіття», «Обмін речовин і перетворення енергії», «Спадковість і мінливість», «Репродукція та розвиток», «Адаптації», «Біологічні основи здорового способу життя», «Сталий розвиток та раціональне природокористування», «Застосування результатів біологічних досліджень у медицині, селекції та біотехнології». Зазначений курс вирішує низку завдань, пов'язаних із формуванням екологічної культури у процесі оволодіння термінологічним апаратом дисципліни, змістовим наповненням основних життєвих законів і закономірностей, розумінням універсальності функціональних ознак життя, принципів та вимог підтримання життєдіяльності організму. Неабияку вагу у реалізації цього завдання мають гуманістичні аспекти біологічних та екологічних проблем, які націлюють людей на турботу про збереження власного здоров'я та безпеки інших людей, розвиток особистої відповідальності за стан довкілля, формування ціннісних орієнтацій на збереження природи, розуміння необхідності узгодження стратегії природи і стратегії людини на основі ідеї універсальності природних зв'язків та самообмеженості, подолання споживацького ставлення до природи. Окремо належить підкреслити доцільність змістових ліній «Екологічна безпека і сталий розвиток» та «Здоров’я і безпека», які проходять крізь усі теми і безпосередньо скеровані на формування основ екологічної культури як бази для зміцнення громадянської відповідальності та соціальної активності студентів.

«Охорона праці та безпека життєдіяльності» $€$ новою інтегрованою дисципліною, предметом вивчення якої є забезпечення комфортної взаємодії людини із довкіллям шляхом вивчення і пізнання закономірностей виникнення небезпечних ситуацій, виявлення шкідливих факторів впливу на людину й середовище, їх прогнозування, формування у студентів відповідальності за особисту та колективну безпеку, а також створення та впровадження міжнародних екологічних стандартів, скерованих на забезпечення сталого розвитку суспільства, основою якого є моделювання різних варіантів розвитку та прогнозування й оптимізація 
їхніх результатів. Метою курсу $є$ набуття знань, умінь та способів запобігання небезпечних ситуацій, пошук шляхів надійного захисту в разі виникнення небезпеки та уміння оперативно ліквідовувати наслідки ії прояву. Зазначений курс охоплює такі галузі знання, як гігієна праці, цивільний захист, пожежна безпека, інженерна психологія, основи медичних знань. Перетинаючись, вони не просто висвітлюють подібну проблематику, а й збагачують одна одну новими пізнавальними колізіями, що поглиблюють процес формування екологічної культури. Звідси випливають завдання дисципліни «Охорона праці та безпека життєдіяльності», які полягають у вмінні ідентифікувати та встановлювати причини та джерела потенційної небезпеки й визначати вірогідність їхнього впливу на організм людини та довкілля, а також, використовуючи нормативно-правову базу, вживати належних заходів для ліквідації та забезпечення незагрозливих умов існування людини та середовища. Важливо виокремити провідну для формування екологічної культури студентів програмову змістову лінію, означену як менеджмент безпеки. Центром уваги його є основні законодавчі акти з безпеки життєдіяльності, зокрема екологічне законодавство, а також основні положення Закону України «Про охорону праці», екологічний контроль та екологічне право.

Програма дисципліни «Фізичне виховання» являє собою нормативний документ, предметом вивчення якого $€$ зміст та організація різноманітних форм раціональної фізичної активності у формі фізичних вправ, які сприяють ефективному формуванню необхідних умінь та навичок, що впливають на оптимізацію фізичного та психофізіологічного стану здобувача вищої освіти, його розумову та фізичну працездатність, гармонійний фізичний та духовний розвиток як необхідний елемент процесу формування екологічної культури. Програма фізичного виховання, яка націлена на збереження та зміцнення здоров'я, охоплює також і закономірності взаємодії людини 3 природою, залежність від середовища, кліматичних умов, механізми адаптації людини, психоемоційні та біологічні ритми, що являють собою регулярне і циклічне повторення інтенсивності життєвих процесів чи станів усіх живих організмів 3 їхньою амплітудою та фазами існування. Однак природне середовище не може стати єдиним регулятором фізичної та екологічної культури людини, яка не обмежується природними даними та генетикою, а неодмінно враховує соціальну потребу комунікації, самовираження і самоствердження. Цей аспект є особливо важливим для усвідомлення потреби формування екологічної культури, що на заняттях спортом розпочинається зі збереження спортивних споруд, інвентарю та елементів обладнання і надалі проявляється у стилі ведення ігор та виконання комплексу фізичних вправ, етичних нормах, які регулюють поведінку спортсмена під час фізкультурної активності, продукуванні естетичних цінностей під час спортивно-показових виступів, олімпіад, парадів тощо. Нині є очевидним оздоровчий та загальнокультурний сенс фізичного виховання, що плекає ідеал фізичної досконалості як певного динамічного стану особистості, невіддільного від ідеалу здорового суспільства.

Плекання цінностей фізичної культури позначає злиття суспільного та особистого інтересу шляхом формування суспільно необхідних потреб, а також трансформації соціального досвіду у властивості особистості, яка прагне найбільш повно реалізувати свої сутнісні сили. Це значною мірою посилює адаптивні можливості організму і створює надійну основу для подальшого існування, позначаючи відкритість та перехід особистості на нові ступені розвитку, охоплюючи емоційно-вольову та мотиваційну сферу, креативні здатності та саморозвиток, простір суб' єктивного самовираження.

Організація фізичного виховання передбачає таке: розуміння ролі фізичної культури у становленні особистості молодшого спеціаліста; оволодіння принципами здорового способу життя; оволодіння системою практичних умінь та навичок зміцнення здоров'я, удосконалення психофізичних здатностей, використання набутого досвіду для досягнення соціально значущих цілей. Реалізуються ці завдання безпосередньо на практичних заняттях фізичної культури, тому їх теоретичний аспект потребує особливої рефлексивної площини, яка створюється у процесі вивчення таких навчальних дисциплін, як «Основи філософських знань», «Основи психології», «Культурологія» та ін. Так, метою вивчення дисципліни «Основи філософських знань» $є$ ознайомлення студентів 3 основними віхами історії розвитку філософії, змістом основних проблем сучасної філософії через засвоєння відповідних філософських знань, долучення до гуманістичного змісту філософського світогляду, а також формування екологічної свідомості та екологічної культури. Існує багато завдань філософського знання, як-от: осмислення сутності і призначення філософії, основних філософських ідей, що супроводжують розвиток людства, основних тенденцій історико-філософського процесу; вміння аналізувати оригінальні філософські тексти; вироблення здатності до філософського осмислення явищ буття, складності сучасного суспільного процесу. Одним 3 провідних завдань залишається формування екоцентричного мислення. На перший план виносяться поняття екологічної свідомості, екологічної етики (принцип благоговіння перед життям 
А. Швейцера), етики відповідальності (А. Наєсс та Г. Йонас), екологічних законів взаємодії суспільства і природних систем (Б. Коммонер), концепція ноосфери (В. Вернадський), екологічні норми. Результативність навчального курсу визначається низкою критеріїв, серед яких найважливішими $\epsilon$ такі: здатність студентів обгрунтовувати свою світоглядну та громадську позицію; застосовувати одержані знання для вирішення професійних задач, розробки соціальних і екологічних проєктів; аналізувати соціально значущі проблеми й процеси, факти і явища суспільного життя; володіти методологією і методами пізнання, творчої діяльності; здатністю до діалогу як засобу вирішення соціальних та екологічних проблем.

Вивчення дисципліни «Основи психології» передбачає підвищення рівня психологічної компетентності студентів 3 метою їх особистісного зростання, корекції власних психологічних станів, створення необхідного комунікативного простору для професійної самореалізації, виявлення мотиваційної сфери, в тому числі і мотивації екологічної поведінки. Одним з першорядних завдань курсу $є$

вміння систематизувати та інтегрувати психологічну інформацію у систему взаємовідносин людини 3 довкіллям, аналізувати та оцінювати часткові та глобальні наслідки взаємодії людини 3 природою, оцінювати особливості психологічного впливу з боку природного, соціального та антропогенного оточення, реакцію людини на дію факторів середовища, зокрема тих, які викликають стрес, зміни мотивів діяльності, прагнень, ціннісних орієнтацій, вчинків, волевиявлень, емоцій і настроїв тощо. Тут оприявнює себе проблема вивчення екологічної свідомості, осмисленої в статусі психологічного явища, а також проблема екологізації та психологізації змісту еколого орієнтованих навчальних програм.

Водночас вивчення культурології передбачає раціональне засвоєння інтегральної культури народів світу, розкриття багатства культури крізь призму національної культури як домінуючого складника, усвідомлення того, що тільки діалог світових культур дає можливість осягнути глибину й особливості власної національної культури [13]. У такому контексті культура розглядається як спосіб буття народу у світі, що виявляється в певній системі світоглядних орієнтирів, цінностей, звичаїв, моральних засад, охоплюючи основні аспекти культурологічних виявів людської особистості, професійні умови фахової діяльності, зміст основних культурологічних концепцій, антропогенезу та процесу соціалізації, механізми залучення людини до культури та екопростору.

Висновки і перспективи подальших розробок. Отже, формування екологічної культури студентів економіко-гуманітарних та інженерних коледжів вписане у контекст загальної екологічної освіти і реалізується засобами інтегративного підходу як певної стратегії в умовах множинності та варіативності освітнього процесу, що націлює науковців на побудову синтетичної освітньої моделі. Формуючи взаємовідносини людини i3 довкіллям, екологічна культура стає одним із типів їі життєдіяльності, позаяк забезпечує сталі координати соціуму, усуває екологічні загрози та внутрішній дискомфорт людини, утверджує високі гуманістичні цінності та пріоритети. Саме вони й актуалізують подальші розробки екологічної культури на інтегративних засадах.

\section{ЛITЕРАТУРА}

1. Антонов Н.С. Интегративная функция обучения. М. : Просвещение, 1994. 304 с. Безрукова В.С. Интеграционные процессы в педагогической теории и практике : монография. Екатеринбург, 1994. $152 \mathrm{c}$.

2. Безрукова В.С. Интеграционные процессы в педагогической теории и практике. Екатеринбург, 1994. С. $152-167$.

3. Бех І.Д. Інтеграція як освітня перспектива. Початкова школа. 2002. № 5. С. 5-6.

4. Бордовская Н.В. Диалектика педагогического исследования: логико-методологические проблемы. СПб : Изд-во РХГИ, 2001. 512 с.

5. Великий тлумачний словник сучасної української мови / уклад. і ред. В.Т. Бусел. К. ; Ірпінь : ВТФ «Перун», 2005. 1728 с.

6. Галицких Е.О. Интегративный подход как теоретическая основа профессионально-личностного становления будущего педагога в университете : дисс. ... донт. пед. наук. СПб, 2002. 387 с.

7. Гриценко Л.И. Теория и практика обучения: интегративный подход : учеб. пособие для студ. высш. учеб. заведений. М. : Издательский дом «Академия», 2008. 240 с.

8. Дубасенюк О.А. Інтегративний підхід до професійного розвитку особистості педагога в умовах цивілізаційних змін. Науковий часопис НПУ імені М.М. Драгоманова. Серія «Творча особистість». К., 2010. Вип. 12 (22). С. 17-20.

9. Про вищу освіту : Закон України. Вищза школа. 2002. № 6. С. 74-121.

10. Козловська I.M. Теоретико-методологічні аспекти інтеграції знань учнів професійної школи (дидактичні основи). Львів : Світ, 1999. 302 с. 
11. Концепція екологічної освіти України : Рішення Колегії Міністерства освіти і науки України № 13/6-19 від 20.12.2001.

12. Концепція Нової української школи. URL: https://www.kmu.gov.ua/.../ukrainska-shkola-compressed.pd.

13. Культурологія : навчальний посібник / за ред. Т.Б. Гриценко. Київ : Центр навчальної літератури, 2008.

14. Лопаткин B.M. Интегративные тенденции в развитии региональной системы педагогического образования. URL: https://www.dissercat.com/content/integrativnye-tendentsii-v-razvitii-regionalnoisistemy-pedagogicheskogo-obrazovaniya.

15. Мойсеюк Н.С. Педагогіка : навчальний посібник. К., 2009. 656 с.

16. Пак М. Теоретические основы интегративного подхода в процессе химической подготовки учащихся профтехучилищ : дисс. ... докт. пед. наук : 13.00 .02 «Теория и методика обучения». СПб, $1991.308 \mathrm{c}$.

17. Романенко M.I. Соціальні та парадигмально-когнітивні детермінанти розвитку сучасної освіти : дис. ... докт. філос. наук : 09.00.10 ; Дніпропетровський національний ун-т. Д., 2003.

18. Сковорода Г. Повне зібрання творів. К. : Наукова думка. Т. 1. 1973. 532 с.

19. Сухаревская Е.Ю. Технология интегрированного урока. Ростов н/Дону : Учитель, 2003. 128 с.

20. Сухомлинська О.В. Історико-педагогічний процес: нові підходи до загальних проблем. К. : АПН, 2003. $68 \mathrm{c}$.

21. Ушинский К.Д. Избранные педагогические сочинения. М. : Педагогика, 1974. 584 с.

22. Философский энциклопедический словарь. М. : Совет. энцикл., 1983. 840 с.

23. Хилько М.І. Екологічна безпека України : навчальний посібник. К., 2017.

24. Шярнас В.И. Принцип интеграции в профессионально-технической педагогике. Интеграционные процессы в педагогической теории и практике: технологический аспект : тез. докл. Свердл. инж.пед. ин-т. Свердловск, 1991. С. 7-10.

25. Яковлев И.П. Интегративные процессы в высшей школе. Л. : Изд-во ЛГУ, 1980, 113 с.

26. Oxford Advanced Learner's Dictionary of Current English / Sixth Edition ; ed. by Sally Wehmeier. Oxford : University Press, 2000. 1540 p.

\section{REFERENCES}

1. Antonov N.S. (1994) Integrativnaya funktsiya obucheniya [Integrative learning function]. M. : Prosveshchenye, pp. 304-400.

2. Bezrukova V.S. (1994) Integratsionnye protsessy v pedagogicheskoy teorii i praktike [Integration processes in pedagogical theory and practice]. Ekaterynburh, pp. 152-167.

3. Bekh I.D. (2002) Integhracija jak osvitnja perspektyva [Integration as an educational perspective]. Pochatkova shkola. \# 5, pp. 5-6.

4. Bordovskaia N.V. (2001) Dyalektyka pedahohycheskoho yssledovanyia: Lohyko-metodolohycheskye problemy [Dialectics of pedagogical research: Logical and methodological problems] / N.V. Bordovskaia. SPb.: Yzd-vo RKhHY, pp. 512-610.

5. VTF "Perun" (2005) Velykyi tlumachnyi slovnyk suchasnoi ukrainskoi movy [Large explanatory dictionary of the modern Ukrainian language]: uklad. i red. V.T. Busel. - K., Irpin, pp. 1728 .

6. Halytskykh E.O. (2002) Yntehratyvnyi podkhod kak teoretycheskaia osnova professyonalno-lychnostnoho stanovlenyia budushcheho pedahoha $v$ unyversytete [Integrative approach as a theoretical basis of professional and personal development of the future teacher at the university] : dys. ... d-ra ped. nauk. SPb, pp. 387.

7. Hrytsenko L.Y. (2008) Teoriya i praktika obucheniya:integrativnyy podkhod: ucheb. posobie dlya stud. vyssh.ucheb. zavedeniy [Theory and practice of teaching: integrative approach: ucheb. allowance for stud. vysh.cheb. establishments] / Hrytsenko L.Y. M.: Yzdatelskyidom “Akademyia”, pp. 240.

8. Dubaseniuk O.A. (2010) Intehratyvnyi pidkhid do profesiinoho rozvytku osobystosti pedahoha v umovakh tsyvilizatsiinykh zmin [An integrative approach to the professional development of the teacher's personality in the conditions of civilizational changes] // Naukovyi chasopys NPU imeni M.M. Drahomanova. Seriia 16. Tvorcha osobystist. K., Vyp. 12 (22). pp. 17-20.

9. Zakon Ukrainy (2002) "Pro vyshchu osvitu" [About higher education]/Vyshcha shkola. \# 6. pp. 74-121.

10. Kozlovska I.M. (1999) Teoretyko-metodolohichni aspekty intehratsii znan uchniv profesiinoi shkoly (dydaktychniosnovy) [Theoretical and methodological aspects of integration of knowledge of vocational school students (didactic bases)]/ Kozlovska I.M. Lviv : Svit, pp. 302.

11. Kontseptsiia ekolohichnoi osvity Ukrainy [The concept of environmental education in Ukraine] Rishennia Kolehii Ministerstva osvity i nauky Ukrainy \# 13,pp.6-19 vid 20.12.2001.

12. Kontseptsiia Novoi ukrainskoi shkoly [Elektronnyi resurs] Rezhym dostupu:https:// www.kmu.gov.ua /.../ ukrainska-shkola-compressed.pd... 
13. Za red. T.B. Hrytsenko (2008) Kulturolohiia: Navchalnyi posibnyk [Culturology: Textbook]. Kyiv : Tsentr navchalnoi literatury.

14. Lopatkyn V. M. (2009) Integrativnye tendentsii v razvitii regional'noy sistemy pedagogicheskogo obrazovaniya, https://www.dissercat.com/content/integrativnye-tendentsii-v-razvitii-regionalnoi-sistemypedagogicheskogo-obrazovaniya. (in Russian).

15. Moiseiuk N.Ye. (2009) Pedaghoghika: [navchaljnyj posibnyk] [Pedagogy: [textbook]]. K., pp.656.

16. Pak M. (1991) Teoretycheskye osnovy yntehratyvnoho podkhoda v protsesse khymycheskoi podhotovky uchashchykhsia proftekhuchylyshch [Theoretical bases of the integrative approach in the course of chemical preparation of pupils of vocational schools] : dys. ... dokt. ped. nauk: 13.00.02 "Teoryiay metodyka obuchenyia". SPb, pp. 308.

17. Romanenko M.I. (2003) Socialjni ta paradyghmaljno-koghnityvni determinanty rozvytku suchasnoji osvity [Social and paradigmatic-cognitive determinants of modern education]:dysertatsiia d-ra filos. nauk : 09.00.10 / Dnipropetrovskyi natsionalnyi un-t. - D. (in Ukrainian)

18. Skovoroda H. (1973) Povne zibrannja tvoriv [Complete collection of works]. K. : Naukova dumka. T. 1., pp. 532 .

19. Sukharevskaia E.Yu. (2003) Tekhnologhyja ynteghryrovannogho urok [Integrated lesson technology]. Rostov n/Donu: Yzd-vo Uchytel, pp. 128.

20. Sukhomlynska O.V. (2003) Istoryko-pedaghoghichnyj proces: novi pidkhody do zaghaljnykh problem [Historical and pedagogical process: new approaches to general problems]. K. : APN, pp. 68.

21. Ushynskyi, K.D. (1974) Izbrannye pedagogicheskie sochineniya [Selected pedagogical works][Tekst] / K.D.Ushynskyi. M. : Pedahohyka, pp. 584 .

22. Filosofskiy entsiklopedicheskiy slovar' (1983) [Philosophical encyclopedic dictionary].M. : Sovet. entsyk1., pp. 840.

23. Khylko M.I. (2007) kologhichna bezpeka Ukrajiny: Navchaljnyj posibnyk [Ecological safety of Ukraine: Textbook]. M. I. Khylko. K. (in Ukrainian)

24. Shiarnas V.Y. (1991) Printsip integratsii v professional'no-tekhnicheskoy pedagogike // Integratsionnye protsessy $\mathrm{v}$ pedagogicheskoy teorii i praktike: tekhnologicheskiy aspect [The principle of integration in professional and technical pedagogy // Integration processes in pedagogical theory and practice: technological aspect]: Tez. dokl. / Sverdl. ynzh.-ped. yn-t. Sverdlovsk, pp. 7-10.

25. Yakovlev Y.P. (1980) Integrativnye protsessy $v$ vysshey shkole [Integrative processes in higher education]. L.: Yzd-vo LHU, pp. 113.

26. Oxford Advanced Learner's Dictionary of Current English / Sixth Edition ; ed. by Sally Wehmeier. Oxford : University Press, 2000, pp. 1540. 